\title{
Current situation of Crimean Congo hemorrhagic fever (CCHF) in Anatolia and Balkan Peninsula
}

\section{Anadolu ve Balkan Yarımadası'nda Kırım Kongo kanamalı ateși (KKKA)'nin güncel durumu}

\author{
Yavuz UYAR ${ }^{1}, \quad$ Iva CHRISTOVA ${ }^{2}$, Anna PAPA ${ }^{3}$
}

\section{ÖZET}

Kırım-Kongo Kanamalı Ateși (KKKA), özellikle Ixodid cinsi kene ısırığı (esas olarak Hyalomma cinsi) tarafından insanlara bulașan viral bir hastalıktır. CCHFV, Bunyaviridae ailesinden Nairovirus cinsine aittir. KKKA virüsü segmentli, tek iplikli, negatif polariteli bir RNA virüsüdür. Hastalığın başlangıcında ani ateș, titreme, şiddetli baș ağrısı, sırt ağrısı ya da bacak ağrıları, kas ağrısı, mide bulantısı ve kusma gibi belirtiler olabilir. KKKA, ilk olarak eski Sovyetler Birliği ve Kongo'da tespit edilmiș olup, hızlıca Avrupa, Asya ve Afrika'nın büyük bölümüne yayılmıștır ve 30'dan fazla ülkede bildirimi yapılmıștır.

İklim değișiklikleri; kenelerin yașam döngüsünü ve göçmen kuşların göç yollarını etkileyebilir, KKKA'nden yoksun bölgelere virüs yayılımında ve kene sayısının artmasında rol alabilir. Tarım ve çiftçilik için arazi kullanımının genișletilmesi ve avcılık faaliyetlerindeki değișiklikler de KKKA insidansında rol oynayabilir. Hayvan ticareti ve nakli KKKA virüsü ile enfekte kenelerin endemik olmayan bölgelere transferine neden olarak konak-kene-virüs dinamiklerini etkileyebilir.

Son yıllarda, Balkanlar'da ve Türkiye'de KKKA epidemiyolojisi değișmektedir. Balkanlar endemik KKKA bölgesi olarak bilinir ve heryıl sporadik vakalar, hatta salgınlar bildirilir. Balkanlar ve Türkiye'de yıllı olarak tespit edilen insan KKKA vakalarının sayısı artmaktadır. Hastalık, Balkanlarda; Bulgaristan, Kosova ve Arnavutluk

\section{ABSTRACT}

Crimean-Congo hemorrhagic fever (CCHF) is a viral disease transmitted to humans mainly by bite of Ixodid ticks, mainly those of the Hyalomma genus. CCHFV belongs to the genus Nairovirus in the family Bunyaviridae. CCHF virus is a segmented, single stranded, negative sense and RNA viruses. The onset of the disease is very sudden, with symptoms such as fever, rigors, intense headache, chills, and backache or leg pains, myalgia, nausea, and vomiting. CCHF originally identified in the former Soviet Union and the Congo, has rapidly spread across large sections of Europe, Asia, and Africa, and has been reported in more than 30 countries.

The climatic changes may affect the life cycle of ticks and the routes of migratory birds, leading to tick abundance and virus distribution in CCHF-free areas. Extended use of land for agriculture and farming and changes in hunting activities play also a role in CCHF incidence, while livestock trade and movement may influence host-tick-virus dynamics resulting in transfer of CCHFV-infected ticks in non-endemic areas.

Recent years, the epidemiology of CCHF is changing in Balkans and Turkey. Balkan Peninsula is a known endemic CCHF area, and sporadic cases and even outbreaks are being reported every year. The annual number of human CCHF cases is increasing in Balkans and Turkey. While Bulgaria, Kosovo and Albania were

\footnotetext{
National Laboratory for Arboviruses and Viral Hemorrhagic Fever Viruses, Virology Reference and Research Lab., Refik Saydam National Public Health Agency (RSNPHA), ANKARA, TURKEY

${ }^{2}$ National Reference Vector-borne Infections and Leptospirosis Lab., National Center of Infectious and Parasitic Diseases (NCIPD), Blvd. Yanko Sakazov 26, SOFIA, BULGARIA

${ }^{3}$ National Reference Laboratory for Arboviruses And Hemorrhagic Fever Viruses, A' Department of Microbiology, Medical School, Aristotle University of Thessaloniki (AUT), THESSALONIKI, GREECE

İletişim/Corresponding Author : Yavuz UYAR

RefikSaydam HifzısshhaMerkezi Başkanliğ, Salgın Hast.Araş.Müd.,Viroloji Ref.veAraş.Lab., Sthhrye-ANKARA

Tel : +903124582452 E-posta/E-mail : yavuz_uyar@yahoo.com

Geliş Tarihi / Received : 19.08 .2011 Kabul Tarihi / Accepted : 27.09.2011
}

DOI ID : 10.5505/TurkHijyen.2011.60352

Uyar Y, Christova I, Papa A. Current situation of Crimean Congo Hemorrhagic fever (CCHF) in Anatolia and Balkan Peninsula. Turk Hij Den Biyol Derg, 2011 ; 68 (3): 139-51. 
bölgelerinde endemik olarak bilinirken, sadece son zamanlarda Türkiye'de (2002 yılında ve o zamandan beri, her yıl birçok vaka) ve Yunanistan'da (2008, ölümcül bir durumda) ortaya çıkmıștır.

KKKA virüsünün $S$ segment tabanlı sekansında filogenetik ağaçta ayırt edilebilir yedi ana "clade" vardır. Şu ana kadar, Balkanlardaki suşların tamamı "Europe 1 clade" içinde yer almıș, ancak Yunanistan ve son yıllarda Türkiye'den AP92 ve AP92-benzeri sușlar da bildirilmiștir. Türk sușlarda yapılan kapsamlı bir çalıșma sușların iki ana "cluster" altında toplandığını ve bunlardan birinin iki alt “cluster”a bölündüğünü göstermiștir.

$\mathrm{Bu}$ derlemede, KKKA hastalığının Balkanlar ve Anadolu'daki güncel durumunun gözden geçirilmesini amaçlanmıștır.

Anahtar Sözcükler: KKKA virüsü, Balkanlar, Anadolu, Türkiye

\section{INTRODUCTION}

Crimean-Congo hemorrhagic fever (CCHF) is a viral disease transmitted to humans mainly by a bite of Ixodid ticks, usually those of the Hyalomma genus, associated with case fatality rate up to $30 \%$ (1). Endemic foci are present in Asia, Europe and Africa. During the recent years the epidemiology of CCHF is changing in Balkans and Turkey, as it emerged in new countries, like Greece, while the annual number of human CCHF cases is increasing in countries where it emerged recently, like Turkey.

Besides tick bite, the virus (CCHFV) can be transmitted by direct contact of infected blood or human and animal tissues; thus intra-family and nosocomial outbreaks have been reported in many countries. Due to this ability for human-to-human transmission, to cause infections in laboratory workers, and the severity of the disease in humans, CCHFV is included in the bioterrorism threat list and it is classified as a WHO Risk Group IV pathogen, meaning that Biosafety level 4 laboratories are required to work with this infectious virus. known endemic regions in Balkans, the disease emerged only recently in Turkey (in 2002, and since then, many cases every year) and in Greece (in 2008, one fatal case).

Seven main clades are distinguishable in the phylogenetic tree based on $\mathrm{S}$ segment sequences of CCHFV. Up to now all strains from Balkans belong into the Europe 1 clade, while in Greece, and, recently in Turkey, AP92 and AP92-like strains are also present. A detailed study on Turkish strains showed that they are grouped into two main clusters, each one further divided into two subclusters.

In this article, we were aimed to review of the current status of CCHF disease in the Balkans and Anatolia peninsula.

Key Words: CCHF virus, Balkans, Anatolia, Turkey

\section{HISTORICAL PERSPECTIVES}

CCHF originally identified in the former Soviet Union and the Congo, has rapidly spread across large sections of Europe, Asia, and Africa, and has been reported in more than 30 countries, thus being the most common among tick-borne viral diseases. The disease was first recognized as "Crimean hemorrhagic fever" in former Soviet Union at the end of World War II, when more than 200 Soviet military personnel and peasants fell ill in western Crimea (2). The etiological agent was first isolated from a febrile child in Belgian Congo (today Democratic Republic of Congo) in 1956 by physician Ghislaine Courtois, and was named “Congo virus"(3, 4). In 1969, Casals demonstrated antigenic similarity between the Crimean virus and the Congo virus that led to the finding of their identity $(5,6)$. Linkage of the place-names resulted in the current names of the disease and the virus.

A detailed review about the epidemiology of CCHF in Asia, Europe and Africa was published in 1979 by Hoogstraal (7). As he mentioned, "CCHFV is enzootic 
in the Palearctic, Oriental, and Ethiopian Faunal Regions, chiefly in steppe, savannas, semidesert, and foothill biotopes where 1 or 2 Hyalomma species are the predominant ticks parasitizing domestic and wild animals". A great step forward the CCHF studies was the use of the newborn mouse virus isolation system. By this method the isolation of various CCHFV strains was successful, which were used for further characterization and classification. The Drozdov strain is one of the initial strains isolated in the USSR; it was isolated from a patient (Drozdov) in Astrakhan (8). In 1968, Drozdov strain was found identical to the Congo virus (strain 3010), resulting in the combination of names. In the same time period (1965) an outbreak in the Chinese province of Xinjiang was attributed to Xinjiang hemorrhagic fever virus (9) which was found to be similar to CCHF. Although initial studies on CCHF were performed in the 40s, recent phylogenetic and evolutionary studies have shown that CCHFV has been circulating for a long time, thus being an "ancient virus", and its most recent common ancestor existed around 1500-1100 BC $(10,11)$.

\section{THE ETIOLOGIC AGENT}

CCHFV belongs to the genus Nairovirus in the family Bunyaviridae. Other genera in the family are bunyaviruses, hantaviruses, phleboviruses, and tospoviruses. Virions of the Bunyaviridae family are lipid-enveloped spherical particles, approximately 80-120 nm in diameter, with a tripartite negative sense single-stranded RNA genome (12). The three RNA segments of the CCHFV genome are named according to lengths as the small (S), medium $(M)$ and large $(L)$, each encapsulated separately and encoding the nucleocapsid $(\mathrm{N})$ protein, the glycoprotein precursor - common ancestor of the two glycoproteins $\mathrm{Gn}$ and $\mathrm{Gc}$, encodes an unusually large polyprotein $(1,684$ amino acids in length) and the RNA-dependent RNA polymerase, respectively.

$\mathrm{N}$ protein is the most abundant protein of CCHFV, and has several essential functions, such as protection of viral RNA and participation in various processes in the replication cycle. Recently it was shown that the $\mathrm{N}$ protein can be subjected to cleavage by host cell caspases resulting in induction of apoptosis; thus, caspase-3-dependent cleavage of $\mathrm{N}$ protein may represent a host defense mechanism against lytic CCHFV infection (13).

Unlike other bunyaviruses, $M$ and $L$ RNA segments of nairoviruses are larger $(14,15)$. As other members of the family Bunyaviridae, CCHFV glycoproteins target to the Golgi apparatus, where most viral assembly takes place.

The virus glycoproteins play important role as receptors for virus adsorption and immune response induction. CCHFV glycoprotein biogenesis is considerably more complex than that of viruses in other genera of the family Bunyaviridae. A striking feature of CCHFV was a hyper-variable mucin-like region upstream of the $\mathrm{N}$ terminus of the mature $\mathrm{Gn}$; its function remains unknown (16, 17). In addition, glycoprotein processing is unique, as the glycoprotein precursor undergoes complex proteolytic processing, and it is initially cleaved into two precursor proteins, PreGn and PreGc, which are subsequently post-translationally processed into the two mature glycoproteins $\mathrm{Gn}$ and Gc [6]. GP38, GP85, and GP160) are additional proteins synthesized from the virus $M$ segment $O R F$ in the endoplasmic reticulum. In the mature virion, the $\mathrm{Gn}$ glycoprotein contains a 176 residue ectodomain followed by a 24 residue transmembrane region and terminates in a long cytoplasmic tail consisting of approximately 100 residues $(17,18)$. The high cysteine content of the $\mathrm{Gn}$ cytoplasmic tail is partly due to the presence of dual, back to back BBa-type zinc fingers, which was found to bind viral RNA, thus, have a likely role in virus assembly (19). All the CCHFV glycoproteins appear dependent on $\mathrm{N}$-glycosylation of $\mathrm{Gn}$ for correct folding, localization and transport (20).

Efficient CCHFV helper virus-independent S, M, and $L$ segment minigenome systems for analysis of 
virus RNA and protein features involved in replication was recently reported (21). Using this system, it was found that the L protein has an ovarian tumor protease domain located in the $\mathrm{N}$ terminus, which was recently shown to be a functional protease, however, with no evidence of $L$ protein autoproteolytic processing (21). The structure of this protease which has subsequently been implicated in downregulation of the type I interferon immune response, was recently elucidated (22).

\section{VECTORS AND RESERVOIRS}

\section{Vectors}

CCHF virus circulates in nature in an enzootic tick-vertebrate-tick cycle; ticks carry the virus from animal to animal and from animal to human. Although CCHFV has been isolated from a variety of tick species, including 28 Ixodidae and 2 Argasidae spp., members of the genus Hyalomma (two-host ticks) are the main vectors of the infection in nature (7). Argasids do not facilitate virus replication and thus can not serve as vectors. Several ixodid tick species, including some members of the genera Hyalomma, Rhipicephalus and Dermacentor, can efficiently transmit CCHFV $(7,23)$; that means that they can acquire the virus through feeding on viremic host, maintain the virus trough different stages of their life cycle, and transmit successfully the virus to the next host. However, Hyalomma marginatum is the principal and most efficient vector of CCHFV in Europe, while $H$. asiaticum kozlovi and $H$. asiaticum asiaticum are the principal vectors in Central Asia (24, 25). The ticks maintain a life-long infection and are competent reservoirs. Besides transstadial route of virus transmission, Hyalomma ticks show transovarial transmission determining its vector competence. In addition, ticks can be infected by co-feeding with infected ticks on uninfected host.

Climate changes may have a significant impact on the reproduction rate of the Hyalomma ticks, and warm winters combined by dry summers are associated with higher tick activity and increased CCHF incidence (26). Global warming may change the epidemiological behaviour of CCHF and in particular it may create a great problem in CCHF prevalent areas by altering the ticks' growth patterns, as well as in areas free of CCHF, by redirecting the migration routes of birds -which host the affected ticks- to areas newly warmed by earth's altered temperature patterns (27).

\section{Reservoirs}

A wide variety of domestic and wild animals have the potential of being CCHFV hosts. Large herbivores serve as the principal reservoirs of the infection being the principal hosts of adult Hyalomma spp. ticks. Seroepidemiological studies have shown the highest antibody levels in large herbivores and no antibodies in birds. The birds are resistant to the infection, but some birds, like ostriches, are susceptible being readily parasitized by Hyalomma ticks and showing a high prevalence of the infection in endemic areas $(28,29)$. Migratory birds may carry infected ticks over long distances and thus may play an important role in CCHF dissemination $(7,30)$. Immature ticks prefer ground-feeding birds and small mammals (e.g. hares, and hedgehogs) that are capable to transmit further the virus transstadially (31). In general, CCHF infection is asymptomatic in all animal species, excluding new born laboratory mice (32). Occupational contact with infected livestock is a common cause of the disease $(33,34)$. Thus, risk groups include farmers, dairy workers, shepherds, veterinarians, agricultural workers and other persons in close contact with livestock and ticks.

\section{CLINICAL FEATURES}

The disease's incubation period is generally short (2-9 days). According to Swanepoel et al. the incubation time after an infected tick bite is 3.2 days, after contact with blood or tissue of infected livestock is 5.0 days, and after contact with blood of a CCHF patient is 5.6 days (35). The onset of the 
disease is very sudden, with symptoms such as fever, rigors, intense headache, chills, and backache or leg pains, myalgia, nausea, and vomiting (36). The typical course of CCHF has four phases: a) incubation phase (3-13 days), b) pre-haemorrhagic phase (1-7 days) characterized by high fever, myalgia, malaise; c) haemorrhagic phase, which on average lasts 2-3 days and starts with petechiae and bleeding from the nose, and from the gastrointestinal, genitourinary and respiratory systems and d) convalescence phase, for the survivors, which starts approximately after the 10th day of illness.

In some patients photophobia, somnolence and signs of menigism can occur. Tachycardia is a common sign, while lymphadenopathy is seen occasionally. Hepatomegaly and splenomegaly are seen in $20-40 \%$ and $14-23 \%$ of the cases, respectively (36). The casefatality rate is $5-35 \%(36,37)$.

\section{LABORATORY FINDINGS}

Thrombocytopenia (platelet count $<150.000 /$ $\mu \mathrm{L}$ ) is the main laboratory finding in $\mathrm{CCHF}$, which is seen early, especially in fatal cases. Disseminated intravascular coagulopathy (DIC) is also noted early (38). Prothrombin time (PT) and activated partial thromboplastin time (aPTT) are prolonged, the fibrinogen level is decreased, and fibrin degradation products (FDPs) are increased. Leucopenia and increased aspartate aminotransferase (AST), alanine aminotransferase (ALT), lactate dehydrogenase (LDH), and creatinine phosphokinase (CK) are common findings in CCHF patients (36). The disordered laboratory tests returned to normal levels within 5-9 days among surviving patients (36).

Criteria predicting a fatal outcome include: 1. white blood cell (WBC) count $\geq 10,000 / \mu \mathrm{L}, 2$. platelet count (PLT) $\leq 20,000 / \mu \mathrm{L}, 3$. AST $\geq 200 \mathrm{U} / \mathrm{L}$ or $A L T \geq 150 \mathrm{U} / \mathrm{L}$, 4. aPTT $\geq 60 \mathrm{~s}$, 5. fibrinogen $\leq 110 \mathrm{mg} /$ $\mathrm{dL}$ (35). These criteria were modified by excluding the criterion of WBC and modifying the level of transaminases to AST $\geq 700 \mathrm{U} / \mathrm{L}$ and ALT $\geq 900 \mathrm{U} / \mathrm{L}$ (39).

\section{DIAGNOSTIC METHODS}

The clinical symptoms and patient medical history (living or traveling in endemic areas) and history of tick bite or exposure to blood, tissue or body fluids of infected livestock or CCHF patient, are the first indicators of CCHF (38). The methods used in the diagnosis of CCHF are: virus isolation, electron microscopy, serological tests and molecular techniques. In 2008 there were 20 laboratories with diagnostic capacities for CCHFV in Europe: 14 in EU Member States, 8 in the endemic regions of the Russian Federation, and one in Turkey; most of these laboratories perform IFA, ELISA, and/or molecular methods, whereas 8 had the capacity to isolate the virus (40).

\section{Virus isolation}

CCHFV isolation procedures should be done in biosafety level 4 (BSL-4) laboratories (1). Isolation in cell culture is simple and rapid; however, it is less sensitive than the intracranial or intraperitoneal inoculation of blood from acute phase patients or homogenized ticks into newborn mice (36).

Since viremia is present during the first five days of the illness, the isolation is successful during the first 2 weeks of the disease. The virus replicates in primary-cell and line cell cultures, including LLC-MK2, Vero, chicken embryo-related cells (CER), SW-13, and BHK21 cells (36). Since cytopathic effects are lacking, the presence of the virus in cell cultures is confirmed by IFA and/or molecular methods.

\section{Antigen detection}

The antigen detection is useful technique for the diagnosis of the disease during the acute phase. Immunocapture ELISA or reverse passive hemagglutination assay technique can be used for the detection of viral antigen of CCHFV. Antigen ELISA test was reported as more sensitive. Immunochemistry studies and in situ hybridization techniques have been also used for the detection of CCHFV in 
formalin-fixed paraffin-embedded tissues, and found to be concordant with virus isolation (41).

\section{Electron microscopy}

Electron microscopy (EM) helps as initial testing. The virus particles are enveloped, spherical, with a diameter of 90-100 nm (1). Using EM particles resembling CCHFV had been found in ultrathin sections of the liver from two fatal cases (42). EM was used also in studies in China and in South Africa where virus particles with diameter of 85-105 nm were seen in blood samples of CCHF patients $(9,43)$.

\section{Serology}

IgG and IgM antibodies are detectable by IFA and ELISA methods from about 7 days after onset of the disease. The IgM declines to undetectable levels after 4 months, and IgG titers remain detectable for at least 5 years (44). Recent or current infection of disease is confirmed by demonstrating seroconversion, or a fourfold or greater increase in the antibody titer in paired serum samples, or IgM in a single sample by using MAC-ELISA (45).

Evaluation of PCR and IgM ELISA used for the laboratory diagnosis of CCHF cases in 2008 in Turkey, according the days after onset of the symptoms, PCR positivity was found in $83.4 \%$ among the samples taken during the first 5 days, and reduced to $67.5 \%$ in the samples taken between 6-10 days. The detection rate of CCHFV-IgM was up to $95 \%$ after the 5 th day when PCR positivity was decreased. As expected, positivity is determined to be high by PCR in the first days, and ELISA-IgM after the 5th day (46).

The specific antibody response is rarely detectable in fatal CCHF cases. Therefore, diagnosis is usually based on the isolation of the virus from the serum or liver biopsy specimens, while viral RNA may be detected in patient's serum or liver tissue.

The ELISA test is generally low specific but more sensitive than IFA and neutralization tests (45).

\section{Molecular methods}

Molecular methods are especially helpful for the rapid diagnosis of CCHF. The assays are typically based on reverse transcriptase (RT) PCR methods using consensus nucleotide primers mainly of the $S$ segment of the virus (47). The genetic material is usually extracted from serum, blood or autopsy tissues. Bodur et al. reported that CCHFV genome is detectable also in the saliva and urine (48).

Real-time RT-PCR assays have been developed, which have a lower contamination rate, and higher sensitivity and specificity than the conventional RT-PCR methods, while viral quantification is also possible (49-52).

Application of RT-PCR combined by sequencing and phylogenetic analysis gives useful data for the molecular epidemiology of CCHF. Such studies provided useful data about the circulation of the CCHFV strains in Balkans and in Turkey $(53,54)$.

\section{EPIDEMIOLOGY}

Crimean-Congo hemorrhagic fever has been known for many years as widely distributed tickborne infection in Africa, the Middle East, central and southwestern Asia, southern provinces of Russia and Balkans (35, 55-61). The geographic distribution of the disease is closely related to the global distribution of Hyalomma spp. ticks, having a $50^{\circ}$ north latitude limit. While Bulgaria, Kosovo and Albania were known endemic regions in Balkans, the disease emerged only recently in Turkey (in 2002, and since then, many cases every year) and in Greece (in 2008, one fatal case). As mentioned previously, climatic changes may affect the life cycle of ticks and the routes of migratory birds, leading to tick abundance and virus distribution in "CCHF-free" areas. Extended use of land for agriculture and farming and changes in hunting activities play also a role in CCHF incidence, while livestock trade and movement may influence host-tick-virus dynamics resulting in transfer of CCHFV-infected ticks in non-endemic areas. 


\section{CCHF in Balkans}

Balkan Peninsula is a known endemic CCHF area, and sporadic cases and even outbreaks are being reported every year. Investigations have shown that CCHF cases occur mostly in men and the most affected age group is that of 20-40 years. The presence of CCHF gradually rises in March and peaks in June and July. Farmers, shepherds, veterinarians, and health personnel are at increased risk for acquiring the infection. Soon after the initial description of CCHF in Crimea in 1944 (2), many cases were recognized in Bulgaria, and later on in former Yugoslavia and Albania. During 2001 a major outbreak was observed in Balkans, with cases being reported in Kosovo, Albania and Bulgaria (51, 58-60, 62-64). As the virus can be transmitted through direct contact of infected blood or tissues, nosocomial cases have been reported (58, 64), as well as intra-family infections (59)(Figure 1).

In Kosovo, the first CCHF cases were registered in 1957 as family outbreaks with 7 fatalities (65). Recent outbreaks occurred in 1995, 2001 and 2004 with 46, 31 and 16 laboratory confirmed cases, respectively (65). Cases were observed also in 2010.

In Bulgaria, CCHF was first described in 1952 in the province of Stara Zagora. Since then, approximately 1,600 cases have been reported with an overall fatality rate of $17 \%$ (Figure 1). Most cases were observed in Plovdiv and Pazardgik (central Bulgaria), Haskovo and Kardgali (southeastern Bulgaria), Shumen (northeastern Bulgaria), and Burgas (eastern Bulgaria) (66). In early spring 2008 a cluster of CCHF cases was observed in southwestern Bulgaria, an area previously considered as not endemic for CCHF (64). Four cases had been confirmed, one of them fatal. Two of the survivors had received hyperimmune gamma globulins against CCHFV. The seroprevalence in human population with a history of tick bite in the endemic areas is around 20\% (60).

It has to be mentioned that a vaccine consisted of mouse brain preparation [inactivated by chloroform, heated at $58^{\circ} \mathrm{C}$, and adsorbed on $\left.\mathrm{Al}(\mathrm{OH}) 3\right]$ is applied since 1974 in Bulgaria, in the frame of an immunization program for medical workers and military personnel in endemic areas. Recently the strain V42/81 which is currently used for the vaccine preparation was genetically characterized (67).

Endemic CCHF foci in Albania are in Kukes and Has districts, in the northeastern part of the country. During the spring and summer of 2001, an outbreak of eight CCHF confirmed cases occurred in Albania, with one nosocomial infection and a cluster of cases within a family (59). CCHFV was the cause of the disease in $38.2 \%$ of 34 CCHF suspected cases during 2003 to 2006; the rest cases were hantavirus infections (11.7\%), leptospirosis $(29.4 \%)$ and rickettsiosis $(2.9 \%)$ cases (62). The seasonal and clinical overlapping among the four diseases is present in Balkans and Anatolia, suggesting that testing for these agents is necessary in cases with fever and haemorrhagic manifestations.

The first CCHF case in Greece was reported in 2008 in northeastern part of the country (53). Since then, no additional cases were observed. The prevalence of CCHFV antibodies in humans in northeastern Greece is 3.1\% (68). A distinct CCHFV strain, AP92, was isolated from Rhicephalus bursa ticks from goats in Vergina, a village in northern Greece (69). This strain is up to date the most divergent of the CCHFV strains. No human case caused by AP92 strain was detected in Greece. Four among 65 persons in the Vergina area were found IgG-positive; however, none of them recalled any symptoms resembling $\mathrm{CCHF}$ (70).

\section{CCHF in Anatolia}

CCHFV has probably been circulating in Turkey for many years; however, the first CCHF cases have been reported in May 2002 (71, 72). The prohibition of hunting and pasturing in the region between 1995 and 2001 led to an increase in the number of wild animals and ticks; this fact might be the cause of the CCHF outbreak $(36,73)$. Migratory birds might also play a role in the transmission of the virus. The first CCHF cases in Turkey were observed in Eastern Anatolia, 
mainly in Tokat and Sivas provinces (74) (Figure 1). This region is a suitable habitat for extended tick activity with its moderate climate and vegetation (75).

According to the Turkish Ministry of Health 1820 CCHF cases occurred in the country (150 in 20022003, 249 in 2004, 266 in 2005, 438 in 2006, 717 in 2007) with a fatality rate of $5 \%$ (37). Two thirds of the cases were reported from 5 cities in the MidEastern Anatolia, most of them in rural areas, while the male-female ratio was $1.13: 1$. Most cases (68.9\%) reported a tick bite or tick contact, and $0.16 \%$ were nosocomial infections (37). The following years the number of cases increased dramatically; 1315 cases have been reported in 2008 and 1318 in 2009 (76). The most abundant tick species collected in Turkey are Rhipicephalus bursa and Hyalomma marginatum; CCHFV has been detected in both species $(77,78)$. The seroprevalence in high risk population in the Tokat and Sivas provinces is $12.8 \%(79)$. In the same region the animal seropositivity is $79 \%(74)$.

\section{GENETIC ANALYSIS OF CCHFV STRAINS IN ANATOLIA AND BALKANS}

Although early serological studies revealed very few differences between CCHFV strains, nucleic acid sequence analysis has demonstrated extensive genetic diversity, particularly between viruses from different geographic regions (80). Seven main clades are distinguishable in the phylogenetic tree based on $\mathrm{S}$ segment sequences: Africa 1, Africa 2, Africa 3, Asia 1, Asia 2, Europe 1 and Europe 2. "Asia 1" contains strains from the Middle East, and “Asia 2" contains strains from China, Kazakhstan, Tadjikistan and Uzbekistan. European strains are closely related and form one well-supported clade (Europe 1), with the exception of the Greek strain AP92, and the AP-92-like strains detected recently in Turkey, which form the "Europe 2" clade (81-83). Genetic differences among clades are approximately $20 \%, 31 \%$, and $22 \%$ in the S, $M$, and L RNA segments, and $8 \%, 27 \%$, and $10 \%$ in the nucleoprotein, glycoprotein precursor, and $\mathrm{L}$ protein, respectively. Up to now all strains from Balkans belong into the "Europe 1" clade (53, 58-60, 64, 71, 84, 85), while in Greece, and, recently in Turkey, AP92 and AP92-like strains are also present (53, 54, 86, 87). AP92-like strains are the most divergent of all CCHFV strains, and as they have not been associated with severe disease in humans, it seems to be less pathogenic than the strains of the other clades. Further studies will provide more information on this issue. A detailed study on Turkish strains showed that they are grouped into two main clusters, each one further divided into two subclusters (54).

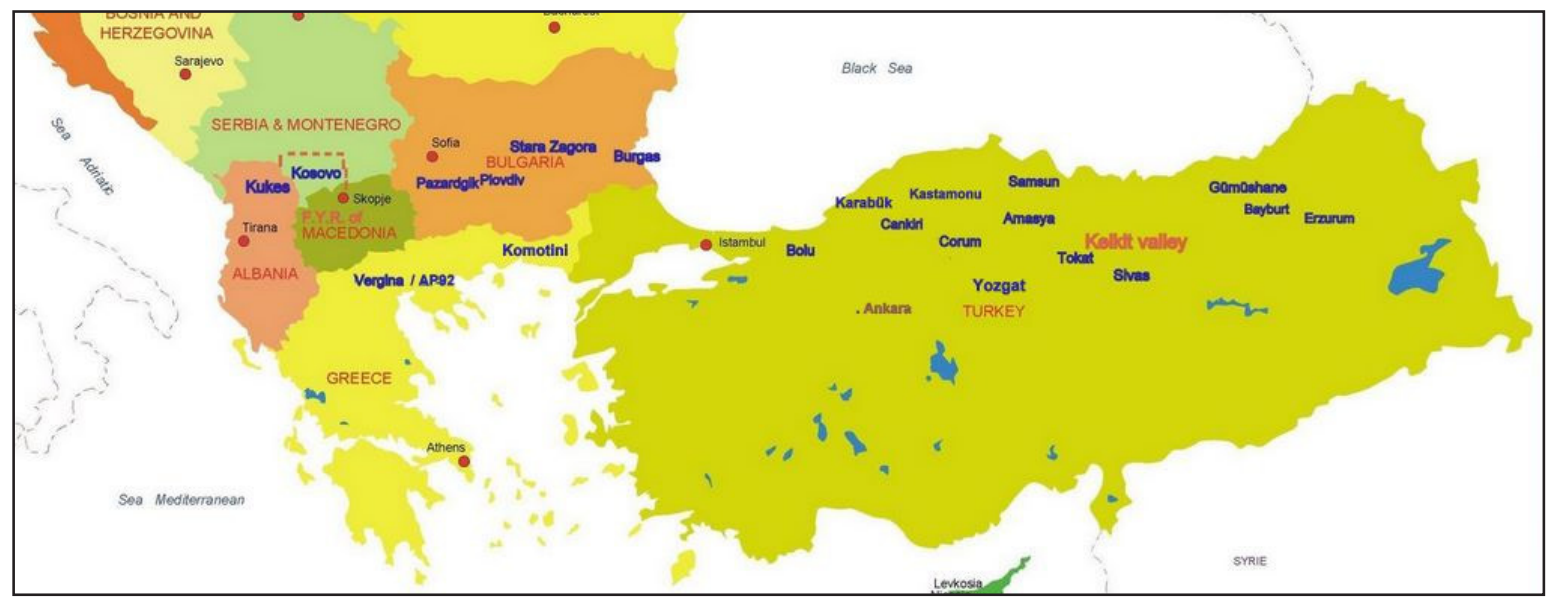

Figure 1. The map shows distribution of CCHV cases (blue colored) in Balkan and Anatolian Peninsula. 
Differences in ticks and vertebrate hosts in distant geographic regions led to differences in evolution of the virus. Although the genetic diversity among clades is high, CCHFV is a very stable virus with evolutionary rates $0.34 \times 10-4$, $1.22 \times 10-4$ and $1.01 \times 10-4$ for the $S, M$ and $L$ segments, respectively (10). Mutation, recombination and reassortment events play a role in the selective forces and the evolutionary history of the virus, resulting in increased complexity of the phylogeny $(81,88,89)$.

\section{CONCLUSIONS}

Given the abundance of Hyalomma and Rhipicephalus ticks, the numerous animals that can serve as hosts, and the favorable climate and ecologic parameters in Balkans and Anatolia, CCHF is an example of a vector-borne disease dispersing widely and rapidly in this area. There are models which show probability of CCHF extending to other countries around the Mediterranean basin suggesting that the vector, veterinarian, and human surveillance should be enhanced (90). Thus, prevention measures, early detection, and epidemiological surveillance are very important for the control of CCHF.

\section{ACKNOWLEDGEMENT}

This work was supported by grant EU-7 Framework project (Crimean Congo Hemorrhagic Fever; Modern Approaches to Diagnostics, Epidemiology, Prevention, Therapy and Preparedness, Project No: 2010- 260427).

\section{REFERENCES}

1. Papa A. Crimean-Congo hemorrhagic fever and hantavirus infections. In: Maltezou H, Gikas A, editors. Tropical and Emerging Infectious Diseases. Kerala, India: Research Signpost; 2010. p. 49-73.

2. Chumakov MP. A new tick-borne virus diseaseCrimean hemorrhagic fever (acute infectious capillary toxicosis) In: Sokolov AE, Chumakov MP, Kolachev AA, editors. Crimean Hemorrhagic Fever (Acute Infectious Capillary Toxicosis). Izdanie Otdel'noj Primorskoj Armii, Simferopol. USSR 1945. p. 13-43.

3. Simpson DI, Knight EM, Courtois G, Williams MC, Weinbren MP, Kibukamu- soke JW. Congo virus: a hitherto undescribed virus occurring in Africa I. Human isolations-clinical notes. East Afr Med J, 1967; 44: 86-92.

4. Simpson DIH, Williams MC, Woodal IP. Four cases of human infection with the Congo agent East Afr Virus Res Inst Rep. 1965: 27-8.
5. Casals J. Antigenic similarity between the virus causing Crimean hemorrhagic fever and Congo virus. Proc Soc Exp Biol Med, 1969; 131(1): 233-6.

6. Woodall JP, Williams MC, Simpson DI. Congo virus - a hitherto undescribed virus occurring in Africa. II. Identification studies East Afr Med J, 1967; 44: 93-8.

7. Hoogstraal H. The epidemiology of tick-borne Crimean-Congo hemorrhagic fever in Asia, Europe, and Africa. J Med Entomol, 1979;15(4): 307-417.

8. Butenko AM, Karganova G. Crimean-Congo Hemorrhagic Fever in Russia and other countries of the former Soviet Union. In: Ergonul O, Whitehouse CA, editors. Crimean Congo Hemorrhagic Fever. A Global Perspective. Dordrecht: Springer; 2007. p. 99-114.

9. Yen YC, Kong LX, Lee L, Zhang YQ, Li F, Cai BJ, et al. Characteristics of Crimean-Congo hemorrhagic fever virus (Xinjiang strain) in China. Am J Trop Med Hyg, 1985; 34(6): 1179-82. 
10. Anagnostou V, Papa A. Evolution of Crimean-Congo Hemorrhagic Fever virus. Infect Genet Evol, 2009; 9(5): 948-54.

11. Carroll SA, Bird BH, Rollin PE, Nichol ST. Ancient common ancestry of Crimean-Congo hemorrhagic fever virus. Mol Phylogenet Evol, 2010; 55(3): 1103-10

12. Schmaljohn CS, Nichol ST. Bunyaviridae. In Fields Virology, Edited by: Knipe DM, Howley PM. Philadelphia: Lippincott, Williams and Wilkins, 5th edition. 2007; Volume 2: 1741-89.

13. Karlberg H, Tan YJ, Mirazimi A. Induction of caspase activation and cleavage of the viral nucleocapsid protein in different cell types during CrimeanCongo hemorrhagic fever virus infection. J Biol Chem, 2011; 286(5): 3227-34.

14. Papa A, Ma B, Kouidou S, Tang Q, Hang C, Antoniadis A. Genetic characterization of the M RNA segment of Crimean Congo hemorrhagic fever virus strains, China. Emerg Infect Dis, 2002; 8(1): 50-3.

15. Honig JE, Osborne JC, Nichol ST. Crimean-Congo hemorrhagic fever virus genome L RNA segment and encoded protein. Virology, 2004; 321(1): 29-35.

16. Papa A, Papadimitriou E, Bozovic B, Antoniadis A. Genetic characterization of the M RNA segment of a Balkan Crimean-Congo hemorrhagic fever virus strain. J Med Virol, 2005; 75(3): 466-9.

17. Sanchez AJ, Vincent MJ, Nichol ST. Characterization of the glycoproteins of Crimean-Congo hemorrhagic fever virus. J Virol, 2002; 76(14): 7263-75.

18. Altamura LA, Bertolotti-Ciarlet A, Teigler J, Paragas J, Schmaljohn CS, Doms RW. Identification of a novel C-terminal cleavage of CrimeanCongo hemorrhagic fever virus PreGN that leads to generation of an NSM protein. J Virol, 2007; 81(12): $6632-42$

19. Estrada DF, De Guzman RN. Structural characterization of the Crimean-Congo hemorrhagic fever virus $G$ tail provides insight into virus assembly. J Biol Chem, 2011; 286(24): 21678-86.

20. Erickson BR, Deyde V, Sanchez AJ, Vincent MJ, Nichol ST. N-linked glycosylation of Gn (but not $\mathrm{Gc}$ ) is important for Crimean Congo hemorrhagic fever virus glycoprotein localization and transport. Virology, 2007; 361(2): 348-55.

21. Bergeron E, Albarino CG, Khristova ML, Nichol ST. Crimean-Congo hemorrhagic fever virus-encoded ovarian tumor protease activity is dispensable for virus RNA polymerase function. J Virol, 2010; 84(1): 216-26.
22. Capodagli GC, McKercher MA, Baker EA, Masters EM, Brunzelle JS, Pegan SD. Structural analysis of a viral ovarian tumor domain protease from the Crimean-Congo hemorrhagic fever virus in complex with covalently bonded ubiquitin. J Virol, 2011; 85(7): 3621-30.

23. Logan $T M$, Linthicum $\mathrm{KJ}$, Bailey $\mathrm{CL}$, Watts $\mathrm{DM}$, Moulton JR. Experimental transmission of CrimeanCongo hemorrhagic fever virus by Hyalomma truncatum Koch. Am J Trop Med Hyg, 1989; 40(2): 207-12.

24. Xia H, Li P, Yang J, Pan L, Zhao J, Wang Z, et al. Epidemiological survey of Crimean-Congo hemorrhagic fever virus in Yunnan, China, 2008. Int J Infect Dis, 2011; 15(7): e459-63.

25. Yaser SA, Sadegh C, Zakkyeh T, Hassan V, Maryam $M$, Ali OM, et al. Crimean--Congo hemorrhagic fever: a molecular survey on hard ticks (Ixodidae) in Yazd province, Iran. Asian Pac J Trop Med, 2011; 4(1): $61-3$

26. Estrada-Pena A. Forecasting habitat suitability for ticks and prevention of tick-borne diseases. Vet Parasitol, 2001; 98(1-3): 111-32.

27. Purnak T, Selvi NA, Altundag K. Global warming may increase the incidence and geographic range of Crimean-Congo Hemorrhagic Fever. Med Hypotheses, 2007; 68(4): 924-5.

28. Capua I. Crimean-Congo haemorrhagic fever in ostriches: A public health risk for countries of the European Union? Avian Pathol, 1998; 27(2): 117-20.

29. Shepherd AJ, Swanepoel R, Leman PA, Shepherd SP. Field and laboratory investigation of CrimeanCongo haemorrhagic fever virus (Nairovirus, family Bunyaviridae) infection in birds. Trans $\mathrm{R}$ Soc Trop Med Hyg, 1987; 81(6): 1004-7.

30. Estrada-Pena A, Zatansever Z, Gargili A, Aktas M, Uzun R, Ergonul $O$, et al. Modeling the spatial distribution of crimean-congo hemorrhagic fever outbreaks in Turkey. Vector Borne Zoonotic Dis, 2007; 7(4): 667-78

31. Apanaskevich DA, Horak IG. The genus Hyalomma Koch, 1844. i. reinstatement of Hyalomma (euhyalomma) glabrum Delpy, 1949 (Acari, Ixodidae) as a valid species with a redescription of the adults, the first description of its immature stages and notes on its biology. Onderstepoort $\mathrm{J}$ Vet Res, 2006; 73(1): 1-12.

32. Shepherd AJ, Swanepoel R, Shepherd SP, McGillivray GM, Searle LA. Antibody to CrimeanCongo hemorrhagic fever virus in wild mammals from southern Africa. Am J Trop Med Hyg, 1987; 36(1): 133-42. 
33. Chapman LE, Wilson ML, Hall DB, LeGuenno B, Dykstra EA, Ba K, et al. Risk factors for CrimeanCongo hemorrhagic fever in rural northern Senegal. J Infect Dis, 1991; 164(4): 686-92.

34. Swanepoel R, Shepherd AJ, Leman PA, Shepherd SP. Investigations following initial recognition of Crimean-Congo haemorrhagic fever in South Africa and the diagnosis of 2 further cases. S Afr Med J, 1985; 68(9): 638-41.

35. Swanepoel R, Shepherd AJ, Leman PA, Shepherd SP, McGillivray GM, Erasmus MJ, et al. Epidemiologic and clinical features of Crimean-Congo hemorrhagic fever in southern Africa. Am J Trop Med Hyg, 1987; 36(1): 120-32

36. Ergonul 0 . Crimean-Congo haemorrhagic fever. Lancet Infect Dis, 2006; 6(4): 203-14.

37. Yilmaz GR, Buzgan T, Irmak H, Safran A, Uzun R, Cevik MA, et al. The epidemiology of CrimeanCongo hemorrhagic fever in Turkey, 2002-2007. Int J Infect Dis, 2009; 13(3): 380-6.

38. Whitehouse CA. Crimean-Congo hemorrhagic fever. Antiviral Res, 2004; 64(3): 145-60.

39. Ergonul O, Celikbas A, Baykam N, Eren S, Dokuzoguz B. Analysis of risk-factors among patients with Crimean-Congo haemorrhagic fever virus infection: severity criteria revisited. Clin Microbiol Infect, 2006; 12(6): 551-4.

40. Maltezou HC, Andonova L, Andraghetti R, Bouloy $\mathrm{M}$, Ergonul $\mathrm{O}$, Jongejan $\mathrm{F}$, et al. Crimean-Congo hemorrhagic fever in Europe: current situation calls for preparedness. Euro Surveill, 2010; 15(10): 19504.

41. Burt FJ, Swanepoel R, Shieh WJ, Smith JF, Leman PA, Greer PW, et al. Immunohistochemical and in situ localization of Crimean-Congo hemorrhagic fever (CCHF) virus in human tissues and implications for CCHF pathogenesis. Arch Pathol Lab Med, 1997; 121(8): 839-46.

42. Tantawi HH, Al-Moslih Ml, Al-Janabi NY, Al-Bana AS, Mahmud MI, Jurji F, et al. Crimean-Congo haemorrhagic fever virus in Iraq: isolation, identification and electron microscopy. Acta Virol, 1980; 24(6): 464-7.

43. Joubert JR, King JB, Rossouw DJ, Cooper R. A nosocomial outbreak of Crimean-Congo haemorrhagic fever at Tygerberg Hospital. Part III. Clinical pathology and pathogenesis. S Afr Med J, 1985; 68(10): 722-8.

44. Shepherd AJ, Swanepoel R, Leman PA. Antibody response in Crimean-Congo hemorrhagic fever. Rev Infect Dis, 1989; 11 Suppl 4: S801-6.
45. Burt FJ, Leman PA, Abbott JC, Swanepoel R. Serodiagnosis of Crimean-Congo haemorrhagic fever. Epidemiol Infect, 1994; 113(3): 551-62.

46. Uyar Y, Carhan A, Albayrak N, Altas AB. [Evaluation of PCR and ELISA-IgM results in the laboratory diagnosis of Crimean-Congo haemorrhagic fever cases in 2008 in Turkey]. Mikrobiyol Bul, 2010; 44(1): $57-64$.

47. Schwarz TF, Nsanze $H$, Longson $M$, Nitschko $H$, Gilch S, Shurie H, et al. Polymerase chain reaction for diagnosis and identification of distinct variants of Crimean-Congo hemorrhagic fever virus in the United Arab Emirates. Am J Trop Med Hyg, 1996; 55(2): 190-6.

48. Bodur H, Akinci E, Onguru P, Carhan A, Uyar $\mathrm{Y}$, Tanrici A, et al. Detection of Crimean-Congo hemorrhagic fever virus genome in saliva and urine. Int J Infect Dis, 2010; 14(3): e247-9.

49. Drosten C, Gottig S, Schilling S, Asper M, Panning M, Schmitz H, et al. Rapid detection and quantification of RNA of Ebola and Marburg viruses, Lassa virus, Crimean-Congo hemorrhagic fever virus, Rift Valley fever virus, dengue virus, and yellow fever virus by real-time reverse transcription-PCR. J Clin Microbiol, 2002; 40(7): 2323-30.

50. Papa A, Drosten C, Bino S, Papadimitriou E, Panning $\mathrm{M}$, Velo $\mathrm{E}$, et al. Viral load and Crimean-Congo hemorrhagic fever. Emerg Infect Dis, 2007; 13(5): 805-6.

51. Duh D, Saksida A, Petrovec M, Dedushaj I, AvsicZupanc T. Novel one-step real-time RT-PCR assay for rapid and specific diagnosis of Crimean-Congo hemorrhagic fever encountered in the Balkans. J Virol Methods, 2006; 133(2): 175-9.

52. Yapar M, Aydogan H, Pahsa A, Besirbellioglu BA, Bodur H, Basustaoglu AC, et al. Rapid and quantitative detection of Crimean-Congo hemorrhagic fever virus by one-step real-time reverse transcriptase-PCR. Jpn J Infect Dis, 2005; 58(6): 358-62.

53. Papa A, Dalla V, Papadimitriou E, Kartalis GN, Antoniadis A. Emergence of Crimean-Congo haemorrhagic fever in Greece. Clin Microbiol Infect, 2010; 16(7): 843-7.

54. Ozkaya E, Dincer E, Carhan A, Uyar Y, Ertek M, Whitehouse CA, et al. Molecular epidemiology of Crimean-Congo hemorrhagic fever virus in Turkey: occurrence of local topotype. Virus Res, 2010; 149(1): 64-70.

55. Chinikar S. Crimean-Congo hemorrhagic fever infection in Iran. In: Ergonul O, Whitehouse CA, editors. Crimean Congo Hemorrhagic Fever. A Global Perspective. 
56. Sun S, Dai X, Aishan M, Wang X, Meng W, Feng $C$, et al. Epidemiology and phylogenetic analysis of Crimean-Congo hemorrhagic fever viruses in xinjiang, china. J Clin Microbiol, 2009; 47(8): 2536-43.

57. Yashina L, Petrova I, Seregin S, Vyshemirskii O, Lvov D, Aristova V, et al. Genetic variability of Crimean-Congo haemorrhagic fever virus in Russia and Central Asia. J Gen Virol, 2003; 84(Pt 5): 1199-206.

58. Papa A, Bozovi B, Pavlidou V, Papadimitriou E, Pelemis M, Antoniadis A. Genetic detection and isolation of Crimean-Congo hemorrhagic fever virus, Kosovo, Yugoslavia. Emerg Infect Dis, 2002; 8(8): 852-4.

59. Papa A, Bino S, Llagami A, Brahimaj B, Papadimitriou E, Pavlidou V, et al. Crimean-Congo hemorrhagic fever in Albania, 2001. Eur J Clin Microbiol Infect Dis, 2002; 21(8): 603-6.

60. Papa A, Christova I, Papadimitriou E, Antoniadis A. Crimean-Congo hemorrhagic fever in Bulgaria. Emerg Infect Dis, 2004; 10(8): 1465-7.

61. Papa A, Maltezou HC, Tsiodras S, Dalla VG, Papadimitriou T, Pierroutsakos I, et al. A case of Crimean-Congo haemorrhagic fever in Greece, June 2008. Euro Surveill, 2008; 13(33).

62. Papa A, Bino S, Papadimitriou E, Velo E, Dhimolea M, Antoniadis A. Suspected Crimean Congo Haemorrhagic Fever cases in Albania. Scand J Infect Dis, 2008; 40(11-12): 978-80.

63. Ahmeti S, Raka L. Crimean-Congo haemorrhagic fever in Kosova : a fatal case report. Virol J, 2006; 3: 85.

64. Christova I, Di Caro A, Papa A, Castilletti C, Andonova L, Kalvatchev N, et al. Crimean-Congo hemorrhagic fever, southwestern Bulgaria. Emerg Infect Dis, 2009; 15(6): 983-5.

65. Humolli I, Dedushaj I, Zupanac TA, Mucaj S. Epidemiological, serological and herd immunity of Crimean-Congo haemorrhagic fever in Kosovo. Med Arh, 2010; 64(2): 91-3.

66. Vasilenko S, Chumakov M, Katzarov G, Mihailov A, Levi V, Kebedgiev $G$, et al. Investigations on Congo-Crimean hemorrhagic fever in Bulgaria II. Serological examinations of people and animals in endemic and nonendemic for CCHF areas [article in Bulgarian]. Epidemiology, Microbiology, and Infectious Diseases, 1971; 8: 150-6.

67. Papa A, Papadimitriou E, Christova I. The Bulgarian vaccine Crimean-Congo haemorrhagic fever virus strain. Scand J Infect Dis, 2011; 43(3): 225-9.
68. Papa A, Tzala E, Maltezou HC. Crimean-Congo hemorrhagic fever virus, northeastern Greece. Emerg Infect Dis, 2011; 17(1): 141-3.

69. Papadopoulos O, Koptopoulos G. Crimean-Congo hemorrhagic fever (CCHF) in Greece: Isolation of the virus from Rhipicephalus bursa ticks and a preliminary serological survey. In: Vesenjak Hirjan Jea (ed.) Arboviruses in the Mediterranean Countries. Gustav Fisher Verlag, Stuttgart, Yugoslavia.; 1980. p. 117-121.

70. Antoniadis A, Casals J. Serological evidence of human infection with Congo-Crimean hemorrhagic fever virus in Greece. Am J Trop Med Hyg, 1982; 31(5): 1066-7.

71. Karti SS, Odabasi Z, Korten V, Yilmaz M, Sonmez M, Caylan R, et al. Crimean-Congo hemorrhagic fever in Turkey. Emerg Infect Dis, 2004; 10(8): 1379-84.

72. Gozalan A, Esen B, Fitzner J, Tapar FS, Ozkan AP, Georges-Courbot MC, et al. Crimean-Congo haemorrhagic fever cases in Turkey. Scand J Infect Dis, 2007; 39(4): 332-6.

73. Bakir M, Ugurlu M, Dokuzoguz B, Bodur H, Tasyaran MA, Vahaboglu H. Crimean-Congo haemorrhagic fever outbreak in Middle Anatolia: a multicentre study of clinical features and outcome measures. J Med Microbiol, 2005; 54(Pt 4): 385-9.

74. Vatansever Z, Uzun R, Estrada-Pena A, Ergonul O. Crimean-Congo Hemorrhagic Fever in Turkey. In: Ergonul O, Whitehouse CA, editors. Crimean Congo Hemorrhagic Fever. A global Perspective. Dordrecht; 2007. p. 59-74.

75. Bursali A, Tekin S, Keskin A, Ekici M, Dundar E. Species diversity of ixodid ticks feeding on humans in Amasya, Turkey: seasonal abundance and presence of Crimean-Congo hemorrhagic fever virus. J Med Entomol, 2011; 48(1): 85-93.

76. Leblebicioglu H. Crimean-Congo haemorrhagic fever in Eurasia. Int J Antimicrob Agents, 2010; 36 Suppl 1:S43-6.

77. Ozdarendeli A, Aydin K, Tonbak S, Aktas M, Altay $\mathrm{K}$, Koksal I, et al. Genetic analysis of the M RNA segment of Crimean-Congo hemorrhagic fever virus strains in Turkey. Arch Virol, 2008; 153(1): 37-44.

78. Tonbak S, Aktas M, Altay K, Azkur AK, Kalkan A, Bolat $Y$, et al. Crimean-Congo hemorrhagic fever virus: genetic analysis and tick survey in Turkey. $\mathrm{J}$ Clin Microbiol, 2006; 44(11): 4120-4.

79. Gunes T, Engin A, Poyraz O, Elaldi N, Kaya S, Dokmetas I, et al. Crimean-Congo hemorrhagic fever virus in high-risk population, Turkey. Emerg Infect Dis, 2009; 15(3): 461-4. 
80. Burt FJ, Swanepoel R. Molecular epidemiology of African and Asian Crimean-Congo haemorrhagic fever isolates. Epidemiol Infect, 2005; 133(4): 659-66.

81. Deyde VM, Khristova ML, Rollin PE, Ksiazek TG, Nichol ST. Crimean-Congo hemorrhagic fever virus genomics and global diversity. J Virol, 2006; 80(17): 8834-42.

82. Hewson R, Chamberlain J, Mioulet V, Lloyd G, Jamil $B$, Hasan $R$, et al. Crimean-Congo haemorrhagic fever virus: sequence analysis of the small RNA segments from a collection of viruses world wide. Virus Res, 2004; 102(2): 185-9.

83. Papa A. Genetic diversity in Crimean-Congo Haemorrhagic Fever virus. Arbo-Zoonet News, 2009: 16-18.

84. Duh D, Nichol ST, Khristova ML, Saksida A, HafnerBratkovic I, Petrovec $M$, et al. The complete genome sequence of a Crimean-Congo hemorrhagic fever virus isolated from an endemic region in Kosovo. Virol J, 2008; 5: 7.

85. Ozdarendeli A, Canakoglu N, Berber E, Aydin K, Tonbak S, Ertek $M$, et al. The complete genome analysis of Crimean-Congo hemorrhagic fever virus isolated in Turkey. Virus Res, 2010; 147(2): 288-93.
86. Midilli K, Gargili A, Ergonul O, Elevli M, Ergin $\mathrm{S}$, Turan $\mathrm{N}$, et al. The first clinical case due to AP92 like strain of Crimean-Congo Hemorrhagic Fever virus and a field survey. BMC Infect Dis, 2009; 9: 90.

87. Elevli M, Ozkul AA, Civilibal M, Midilli K, Gargili A, Duru NS. A newly identified Crimean-Congo hemorrhagic fever virus strain in Turkey. Int $\mathrm{J}$ Infect Dis, 2009; 14 Suppl 3: e213-6.

88. Hewson R, Gmyl A, Gmyl L, Smirnova SE, Karganova $G$, Jamil B, et al. Evidence of segment reassortment in Crimean-Congo haemorrhagic fever virus. J Gen Virol, 2004; 85(Pt 10): 3059-70.

89. Lukashev AN. Evidence for recombination in Crimean-Congo hemorrhagic fever virus. J Gen Virol, 2005; 86(Pt 8): 2333-8.

90. Maltezou HC, Papa A. Crimean-Congo hemorrhagic fever: risk for emergence of new endemic foci in Europe? Travel Med Infect Dis, 2010; 8(3): 139-43. 


\section{TELIF HAKKI DEVRI / COPYRIGHT RELEASE}

\section{REFIK SAYDAM HIFZISSIHHA MERKEZI BAŞKANLIĞI / REFIK SAYDAM NATIONAL PUBLIC HEALTH AGENCY \\ Türk Hijyen ve Deneysel Biyoloji Dergisi / Turkish Bulletin of Hygiene and Experimental Biology}

$$
\text { .........../20... }
$$

Makale Türü/Article Type:

(...)Araştırma/Research (...)Derleme/Review _...)Olgu Sunumu/Case Report (...)Editöre Mektup/Letter to Editor Makale Başlı̆ı̆/Article Entitled :

Sayın Editör,

Yayınlanması dileğiyle Türk Hijyen ve Deneysel Biyoloji Dergisíne gönderdiğimiz makalenin yazarları olarak;

1. Derginizde yayımlanmak üzere yollamış olduğumuz makalenin orjinal olduğunu; bilimsel ve etik sorumluluğunun bize ait olduğunu,

2. Makalenin; derginizdeki değerlendirme sürecinde başka bir yayın organına yayımlanmak üzere gönderilmediğini ve gönderilmeyeceğini,

3. Makalenin; kişilik ve telif haklarına aykırı kanun dışı maddeler içermediğini,

4. Yayın haklarının Türk Hijyen ve Deneysel Biyoloji Dergisi'ne ait olduğunu kabul ve beyan ederiz.

Dear Editor,

Here, we affirm and warranty as the author(s) of this manuscript submitted to Turkish Bulletin of Hygiene and Experimental Biology that;

1. The article I / We submitted to the Bulletin is original and responsibilities are belong to us ethically and scientifically,

2. The article is not currently being considered for publication by any other journal and will not be submitted for such review while under the evaluation of this bulletin,

3. The article contains no unlawful statements and does not contain any materials that violate any personal or proprietary rights,

4. The article publishing rights belong to Turkish Bulletin of Hygiene and Experimental Biology.

(...)1)

Yazışma Adresi/Corresponding Address :

Tel/Phone :.....

Faks/Fax

İmza/Signature :

(...)2)

e-posta/e-mail

Yazışma Adresi/Corresponding Address

Tel/Phone :.

..Faks/Fax:

Imza/Signature

(...)3) e-posta/e-mail :

Yazışma Adresi/Corresponding Address

Tel/Phone :.....

..Faks/Fax

Imza/Signature :

(...)4) e-posta/e-mail :

Yazışma Adresi/Corresponding Address

Tel/Phone :

.Faks/Fax :

İmza/Signature :

(...)5)

Yazışma Adresi/Corresponding Address

Tel/Phone

..Faks/Fax

e-posta/e-mail :

Not / Note : 1. İletişim kurulacak yazarın yanına $(X)$ işareti koyunuz / Please indicate the corresponding author with (X)

2. Formu aşağıdaki adrese faks/posta yolu ile gönderiniz veya elden teslim ediniz / Please send this form to the address below by faks or mail or deliver personally.

Refik Saydam Hıfzıssıhha Merkezi Başkanlığı / Refik Saydam National Public Health Agency

Türk Hijyen ve Deneysel Biyoloji Dergisi / Turkish Bulletin of Hygiene and Experimental Biology

Yayın ve Dokümantasyon Müdürlüğü / Department of Publication and Documentation

Sağlık Mah. Adnan Saygun Cad. No: $5506100 \quad$ Sihhiye-ANKARA-TURKEY

Tel/Phone : +903124582364Ｆaks/Fax : +903124582408ｅ-posta/e-mail : turkhijyen@rshm.gov.tr 